\title{
E-Belge Sistemleri Üzerine Davranışsal Tutum ve Kullanım Niyetlerinin İncelenmesi: Karabük İli Muhasebe Meslek Mensupları Örneği ${ }^{*}$
}

\author{
Cihan BAYRAKTAR ** \\ Murat YILDIRIM***
}

\section{ÖZET}

Maliye Bakanlı̆g, yürürlüğe koymuş olduğu elektronik fatura, elektronik defter, elektronik arşiv, elektronik beyanname ve elektronik tebligat sistemleri ile işletmelerin muhasebe süreçlerinin işlevselliğinin ve denetiminin daha iyi seviyelere ulaşmasını amaçlamaktadır. Bu nedenle, ilgili sistemlerin daha geniş kapsamda kullanımının sağlanması için gerekli yasal düzenlemeler yapılmıştır. Ancak bu sistemlerin istenen amaca ulaşabilmesi için, Maliye Bakanlığl tarafindan sunulan hizmet ve yasal düzenlemelerin yanında, muhasebe meslek mensuplarl tarafindan üst seviyede benimsenmesi ve üst seviyede kullanılması gerekmektedir. Bu çalışma, ilgili elektronik belge sistemlerinin muhasebe meslek mensupları tarafindan ne derecede kabullenildiğini ortaya koymayı amaçlamaktadır. Elde edilen verilerin analizi sonucunda e-belge sistemlerinin kabullenme durumunun kararsızım ile katıllyorum arasinda olduğu tespit edilmiştir.

Anahtar Kelimeler: Bilgi ve İletişim Teknolojileri, E-İşletme, Muhasebe Bilgi Sistemi, E-Belge, E-Fatura, E-Defter, E-Arşiv, E-Beyanname, E-Tebligat.

JEL Siniflandirmast: M15, M41, O33, O38.

Examination of Behavioral Attitude and Usage Intentions on E-Document Systems: The Case of Karabük Professional Accountants

\section{ABSTRACT}

The Ministry of Finance aims at to achieve better functionality and control of the accounting processes of enterprises with electronic invoice, electronic ledger, electronic archive, electronic declaration and electronic notification systems that are put into effect. Thus, legal arrangements have been made to widen the usage of related systems. However, to achieve the desired results, besides services and legal regulations offered by the Ministry of Finance, those systems must be used and adopted by professional accountants on upper level. This study aims to reveal the acceptance level of related electronic document systems by professional accountants. As a result of the analysis of the obtained data, it has been determined that the acceptance status of the e-document systems is between unstable and participating.

Keywords: Information and Communication Technology, E-Business, Accounting Information System, E-Document, E-Invocing, E-Ledger, E-Archieve, E-Declaration, E-Notification.

Jel Classification: M15, M41, O33, O38.

\footnotetext{
* Muhasebe Meslek Mensuplarının E-Belge Sistemleri Üzerine Davranışsal Tutumları ve Kullanma Niyetlerinin İncelenmesi: Karabük İli Örneği isimli yüksek lisans tezinden üretilmiştir.

** Öğr. Gör. Cihan Bayraktar, Karabük Üniversitesi Eskipazar Meslek Yüksekokulu,

cihanbayraktar@karabuk.edu.tr

*** Doç. Dr. Murat Yıldırım, Karabük Üniversitesi İşletme Fakültesi, muratyildirim@karabuk.edu.tr
} 


\section{GİRiş}

Günümüz şartlarında önemli ölçüde kullanıma sahip olan e-belge sistemlerinin temeli, bilgi ve iletişim teknolojileri tarafından oluşturulmaktadır. Bilgi ve iletişim teknolojileri, kişilerin ve kurumların aralarında gerçekleştirilen tüm ilişkilerin alt yapısını oluşturmakla birlikte bu ilişkilerin eskiye oranla daha hızlı ve sağlam temeller üzerinde gerçekleşmesini sağlamaktadır. Hiçbir kişi ve kurum, gerçekleşen bu büyük değişime direnememiştir. Bunun sonucu olarak, işletmeler içerisinde bütün faaliyetler bilgi iletişim teknolojileri alt yapısı kullanılarak gerçekleştirilmeye başlanmış ve e-işletme kavramı ortaya çıkmıştır. İşletmelerde gerçekleşen e-işletme dönüşümünün bugüne kadar en yoğun yaşandığı birim, muhasebe birimidir. Maliye Bakanlığ tarafından çıkarılmış olan e-fatura, e-defter, e-beyanname, e-arşiv ve e-tebligat gibi e-belge sistemleri, son yıllarda bu konuda yapılan atılımlara verilebilecek ön plandaki örnekler arasındadırlar.

Çalışma Karabük ilinde faaliyet gösteren muhasebe meslek mensuplarının e-belge sistemlerini benimseme seviyelerini ortaya çıkarmayı amaçlamaktadır. Çalışmanın ikinci bölümünde işletmelerde bilgi ve iletişim teknolojilerinin gelişimine yer verilmiştir. Üçüncü bölümde elektronik belge kullanımı üzerinde bilgiler sunulmuştur. Dördüncü bölümde çalışmada kullanılan veri, yöntem ve uygulama hakkında bulgular tartışılmıştır. Son bölümde çalışmada ulaşılan başlıca bulgular özetlenmiştir.

\section{2. İŞLETMELERDE BILGI VE İLETIŞSiM TEKNOLOJILERININ GELIŞSiMI}

Bilgi ve iletişim teknolojileri, karar verme, kontrol etme ve problem çözme konularında işletmelerin ihtiyaç duydukları faydalı bilgiyi üretmek amacıyla kullanılmaktadır. $\mathrm{Bu}$ süreçte girdi, işlem ve çıktı öğelerinde faydalanmaktadırlar. Girdi, işletme içinden veya dışından gelen veriler tarafından oluşturulmaktadır. İşlem, girdi ile birlikte gelen verileri yorumlayarak işletme için gerekli bilgilerin oluşturulduğu bir süreçtir. Çıktı ise, işlenerek oluşturulmuş verilerin ilgili kişilere sunulması olarak adlandırılmaktadır. Ayrıca, oluşturulan bilgiler doğrultusunda, girdi aşamasında doğru bilgilere ulaşılıp ulaşılmadığ konusunda bir sağlama işlemi gerçekleştiren geri bildirim bölümü de faydalı olarak kullanılmaktadır. Bu sayede bilgi ve iletişim teknolojileri, özellikle yöneticilerin ve diğer işletme ile ilgili tarafların karar verme davranışlarında ciddi anlamda yardımcı olmaktadır (Tahirov, 2009: 123).

\subsection{Elektronik İşletme}

Elektronik işletme (e-işletme) kavramı, faaliyetlerinin yürütülmesi amacıyla, bilgi ve iletişim teknolojilerinin işletmede kullanılması olarak tanımlanır (Laudon ve Laudon, 2009: 67). Ayrıca e-işletme, işletmenin kendisi ile müşterileri, tedarikçileri ve diğer ilgili tarafları ile arasındaki iletişimin ve işbirliğinin en üst seviyeye çıkarılabilmesi için internet, intranet ve extranet gibi bilgisayar ağlarının kullanılması olarak açıklanmıştır (Combe, 2006: 1). 
Günümüzde kullanılan e-işletme kavramının temeli, 1969 yılında iki bilgisayar arasında ağ bağlantısının kurulması ile atılmıştır. İnternet olarak adlandırılan bu ağ bağlantısının, istenilen bilgiyi çok uzaklara birkaç saniye içerisinde gönderebilmesinin fark edilmesiyle birlikte çok hızlı bir yayılım göstermiştir. 1990'lı yılların başlarında, oluşan bilinç aracılığı ile iş süreçlerinin yeniden tasarlanmaya başlanması e-işletme olgusunun da var olmaya başlamasına sebep olmuştur. 1990'ların ortalarına doğru internet kullanımının ve kullanıcı sayısının ciddi oranda artması sayesinde, işletmeler birçok ticari faaliyetlerini de bilgi ve iletişim teknolojilerini kullanarak çok daha hızlı ve güvenli bir şekilde yapabileceklerini keşfetmişlerdir. Özellikle işletmeler, 1990'ların sonları itibari ile bilgi ve iletişim teknolojilerine iyice uyum sağlamaya ve ticari süreçteki tüm iletişim faaliyetlerini internet vasıtası ile gerçekleştirmeye başlamışlardır. İşletmeler, rakipleri, müşterileri, tedarikçileri, finans kuruluşları, sosyal güvenlik kuruluşları ve vergi daireleri gibi birçok kurumla bilgi ve iletişim teknolojileri üzerinden iletişim kurabilecek ve bilgi paylaşabilecek duruma gelmişlerdir. Bunun sonucunda, büyügünden küçügüne kadar, işletmelerin önemli bir kısmı yaşanan bu gelişmelere dahil olabilmek için, yeniden yapılanma sürecine girmişlerdir (Dinç ve Varıc1, 2008: 194).

Bilgi ve iletişim sistemlerini kendi bünyesine dahil etmiş olan işletmelerde, birimler tarafından üretilen bilgilerin çeşitli elektronik ortamlarda hızlı ve ortak bir şekilde kullanılması mümkün olmuştur. Yeni belge tasarımları, bakım onarım zamanları, çalışan dokümanları ve politikaları, üretim planlamaları, muhasebe işlemleri ve bunların dışında kalan diğer işletme faaliyetlerine ait tüm bilgi ve belgeler, ulaştırılması gereken tüm kişilere aynı anda gönderilebildiği ve aynı hızla incelenebildiği ve yönetimsel kararlara etki edebildiği için yönetimin etkinliğini ve verimliliğini önemli ölçüde arttırmaktadır (Sevim, 2003: 63).

\subsection{Muhasebe Uygulamalarında Bilgi ve İletişim Teknolojileri}

Bilgi ve iletişim teknolojileri, muhasebe işlemlerinde önemli roller üstlenmiştir. Bilgi ve iletişim teknolojileri, toplanan verilerin kayıt edilmesi, saklanması, çeşitli süreçlerden geçirilerek yeni bilgilerin üretilmesi, üretilen bu yeni bilgilere erişilmesi, kaydedilmesi ve ilgililere ulaştırılması konusunda etkin bir şekilde görev yapan sistemler olarak görülmektedir (Acar ve Öksüz, 2013: 65).

Son yıllarda yapılan çalışmalar sonucunda, muhasebe biriminin bilgi ve iletişim teknolojileri ile entegrasyonu artırılmış ve birim içerisinde gerçekleştirilen işlemler bilgisayar ve internet ortamına aktarılmaya başlanmıştır. Elektronik fatura(E-Fatura), elektronik defter(E-Defter), elektronik arşiv(E-Arşiv), elektronik beyanname(E-Beyanname) ve elektronik tebligat(E-Tebligat) uygulamaları bilgi ve iletişim teknolojilerinin muhasebe alanındaki güncel uygulamaları olarak gösterilebilir. Bu sayede muhasebe işlemleri için gerekli tüm belgeler elektronik ortamda hazırlanacak ve ilgili kişilere gönderilerek kullanılacaktır. Bu sistemde kayıtların daha düzenli tutulmasıyla birlikte, verimlilik ve rekabet gücünün artması amaçlanmaktadır (Uyar, 2006: 8). 


\section{ELEKTRONIK BELGE UYGULAMALARI}

Yaygın anlamda belge, belirli bir amaç için yazılmış veya çizilmiş bilgileri içeren bilgi taşıyıcısı anlamına gelmektedir. Belgenin anlam merkezinde genellikle, bir birim olarak belgenin, kolay bir şekilde oluşturulması, iletilmesi, saklanması ve kullanılmasını barındıran bir ifade bulunmaktadır (Björk, 2003: 105). E-belge ise Maliye Bakanlığı tarafından yayınlanmış olan 397 Sıra No'lu VUK Genel Tebliğinde (2010: 2), şekil hükümlerinden bağımsız olarak Vergi Usul Kanununa göre düzenlenmesi zorunlu olan belgelerde yer alan bilgileri içeren elektronik kayıtlar bütün olarak tanımlanmıştır.

Son yıllarda dünyada ve ülkemizde yaşanan köklü değişimler ve geliştirilen teknolojiler, yaşamın tüm alanlarında son derece etkili olmuştur. Bilgi ve iletişim teknolojileri alanında yaşanan gelişmelerde belge kavramına "e-belge" kavramını eklemiştir. Bunun sonucunda işletmelerde e-belge ve e-belge yönetim sistemleri önemli bir yere sahip olmuştur. E-belge ve e-belge yönetim sistemleri, belge ve belge yönetim sistemleri ile tamamen aynı içeriğe sahip olmasına rağmen onlardan ayrılmalarını sağlayan en önemli etken, bu tür belgelerin elektronik ortamlarda üretiliyor ve kullanılıyor olmasıdır (Ermiş, 2006: 140).

E-belge yönetim sistemlerinin en önemli avantaj1, zaman ve tedarik konusundaki tasarruflardan daha çok, işletmenin iş süreçlerinin daha doğru bir organizasyon içerisinde gerçekleşmesi olarak ifade edilebilir. E-belge yönetim sistemlerinin kullanıcılara sağladığ diğer avantajlar şu şekilde ifade edilebilir (Burtylev vd., 2013: 1-2):

- Uygulamaların otomatik gerçekleşmesi ve organizasyonun her aşamasında şeffaflık sağlamasından dolayı daha etkilidir.

- $\quad$ Uluslararası kaideler çizgisinde giden kaliteli sistemlerini destekler.

- $\quad$ Bilginin verimli bir şekilde depolanmasını, yönetilmesini ve bilgiyle erişimi destekler.

- Genel anlamda işletmenin periyodik faaliyet aktivitelerinin kayıtlarını tutar.

- $\quad$ İşs süreçlerini, uygulamalarını ve görüntüleme mekanizmasını en iyi seviyeye getirir.

- İşletme içerisindeki kağıt belge sirkülasyonunun tamamen dişlanması veya maksimum seviyede azaltılması işletmelerde kaynak tasarrufu sağlar.

- $\quad$ Zorunlu istisna veya bir eylemsel elektronik arşiv ile birlikte kağıt belgenin gerçek sadeleştirmesini ve ucuz depolanmasını sağlar.

\subsection{Elektronik Fatura}

Türkiye'de 397 sıra no'lu Vergi Usul Kanunu(VUK) tebliği ile hayata geçirilen ve 5 Mart 2010 tarihinden itibaren uygulamada olan e-fatura, veri format ve standardı Gelir İdaresi Başkanlığı tarafından belirlenen, Vergi Usul Kanunu gereği bir faturada yer alması gereken 
tüm bilgileri içerisinde yer aldığı, satıcı ve alıcı arasındaki iletişimin merkezi bir platform üzerinden gerçekleştirildiği elektronik bir belgedir. E-fatura uygulamaları Gelir İdaresi Başkanlığı tarafından yönetilmektedir. E-fatura uygulamasındaki amaç belirli bir biçim ve standarda göre satıcıların ve alıcıların arasında düşük maliyetli, daha güvenli ve daha hızlı bir iletişim sistemi kurmaktır. E-fatura uygulaması 397 sıra no'lu VUK tebliği ile tüzel kişiler tarafından, 416 sıra no'lu VUK tebliği ile de gerçek kişiler tarafından kullanılabilmektedir. Ayrıca 421 sıra no'lu VUK tebliğinin yayınlanması ile bilgi işlem alt yapısı yeterli olmayan kişilerinde e-fatura uygulamasından kolayca yararlanabilmeleri için Özel Entegratörlük müessesesi uygulamaya konulmuştur (http://www.efatura.gov.tr/efaturahakkinda.html: 2015).

Vergi Usul Kanunu 232. maddesinde satıcıların bir alışveriş sonucu müşteriye fatura düzenleyip vermesinin, aynı şekilde müşterinin de bu faturayı istemesi ve almasının zorunlu olduğu belirtilmiştir. 397 sıra no'lu VUK Genel Tebliğinde ise, faturanın elektronik bir belge olarak düzenlenmesi, verilmesi, saklanması ve gerektiğinde ibraz edilmesi gibi konularda düzenlemeler bulunmaktadır. Bu sebeple, bir alışveriş sonucu fatura düzenlemesi zorunlu olan satıcılar, genel standartlar çerçevesinde basılı (kağıt) fatura düzenleyebilme hakkında sahiptir. Aynı şekilde tebliğde yer alan hükümler çerçevesinde de e-fatura düzenleyebilmektedirler. Ancak satıcılar basılı fatura ve e-faturadan sadece bir tanesini düzenleyebilirler. İkisinin aynı anda düzenlenmesi mümkün değildir. Ayrıca e-fatura uygulamasına geçmiş mükelleflerde müşteri talep ettiği takdirde basılı fatura düzenlemek zorundadırlar (Karadeniz, 2012: 5).

E-fatura süreci, temelde kağıt fatura süreci ile önemli ölçüde benzerlik göstermektedir. Bir müşteri, bir mal veya hizmetin karşılığ 1 olarak gereken ödemeyi yaptıktan sonra, satıcı bunun karşılığında fatura düzenleyecektir. Ancak manuel sistemin aksine hazırlayacağ fatura, elektronik ortamda hazırlanacaktır. Hazırlanan e-fatura, internet ve intranet veri yolları kullanılarak ilk önce fatura bilgilerini inceleyecek olan işletme yöneticisine ulaşır. Yönetici incelemelerini tamamladıktan sonra da faturayı onaylayarak muhasebe meslek mensubuna gönderir. Kendisine gelen e-faturayı alan muhasebe meslek mensubu ödeme bilgilerini elektronik ortamda oluşturur ve fatura bilgilerini e-deftere kaydeder. Ayrıca ilerleyen süreçte fatura bilgilerinin tekrar incelenebilmesi için fatura, elektronik ortamda oluşturulmuş e-arşiv sistemine kaydedilir (Voutilamen ve Pento, 2003: 223-224).

Ülkemizde e-faturaların düzenlenmesi ve iletilmesine ilişkin konular Maliye Bakanlığ1 tarafından hazırlanmış olan 397 Sıra No'lu VUK Genel Tebliğinde (2010: 4-7) belirtilmiştir. $\mathrm{Bu}$ tebliğe göre, e-fatura çalışmaları kapsamında Gelir İdaresi Başkanlığı tarafından oluşturulmuş Elektronik Fatura Kayıt Sistemi (EFKS) sistemi, sınırlı sayıda mükellef ile kullanılmaya başlanmıştır. Bu mükelleflerin EFKS sistemini kullanarak hazırlayacakları efaturalarda Vergi Usul Kanunu kapsamında geçerli faturalar hükmünde sayılacaklardır. EFKS sistemi kullanan mükelleflerin dişında kalan e-fatura mükellefleri için ise, e-faturanın ilgili tebliğde bulunan usul ve esaslara uygun olarak düzenlenmesi, gönderme ve alma işlemlerinin de Gelir İdaresi Başkanlığı tarafından oluşturulan e-fatura uygulaması aracılığı ile gerçekleştirilmesi zorunludur. Faturaların e-belge olarak düzenlenmesi ve gönderilmesine 
ilişkin biçim ve standartlar http://www.efatura.gov.tr adresinde duyurulmuştur. Bu tebliğde belirtilen usul ve esaslar ile uygulanması gereken biçim ve standartlara uygun olarak düzenlenmeyen, düzenlense dahi e-fatura uygulaması aracılı̆̆ ile gönderilmeyen veya alınmayan e-faturaların geçerlilikleri bulunmamaktadır. Ayrıca mükellefler 397 sıra no'lu tebliğde belirtilmeyen hususlar konusunda da Vergi Usul Kanunu ve ilgili diğer tüm kanun ve düzenlemelerde yer alan hususlara uymak zorundadırlar.

\subsection{Elektronik Defter}

E-defter, şekil hükümlerinden bağımsız olarak Vergi Usul Kanunu ve/veya Türk Ticaret Kanunu'na göre tutulması zorunlu olan defterlerde yer alması gereken bilgileri kapsayan elektronik kayıtlar bütünü olarak tanımlanmıştır (Maliye Bakanlığı ve Gümrük Ticaret Bakanlığı, 2011: 2). İşletmeler tarafından tutulması gereken defterlerin, belirlenen biçim ve standartlara uygun bir biçimde elektronik olarak hazırlanması, kağıda bastırılmadan kaydedilmesi ve saklanması, kaynağının değişmezliğinin ve bütünlüğünün garanti altına alınması ve gerekli görüldüğü takdirde ispat aracı olarak kullanılabilmesine imkan veren hukuki ve teknik düzenlemelerin tamamı e-defter olarak ifade edilebilmektedir (Acar ve Öksüz, 2013: 76).

İhtiyaçlar doğrultusunda özel veya paket yazılım üreten işletmeler ile yazılımlarını kendi geliştiren mükelleflerin, 1 No'lu E-Defter Genel Tebliği'ndeki şartlara uygun e-defter oluşturan, kaydeden, onaylayan ve muhafaza eden yazılımların Gelir İdaresi Başkanlığı tarafindan onaylanmaları gerekmektedir. Yazılımların onaylanması konusunda gerekli başvurular yapıldıktan sonra, http://www.edefter.gov.tr sitesinde duyurulan veri standartları ve biçime uygun olarak üretilmiş olan, e-defterlerin üretilmesi, kaydedilmesi ve bunların ibrazına ilişkin şartları sağlayan, mali mühür, e-imza, mobil imza ve zaman damgası kullanımını doğru bir şekilde gerçekleştiren, http://www.edefter.gov.tr adresinde belirtilen edefter uygulaması onay süreçlerine ilişkin işlemleri yerine getirebilen yazılımlara, kullanılmaya başlanabilmesi için gerekli onay verilmektedir (Kumkale, 2013: 117-118).

E-defterlerin denetlenmesi konusunda yapılacak bazı düzenlemeler ile denetim elemanlarının e-defterlere uzaktan erişimin yolu açlabilecektir. Günümüz bilgi ve iletişim teknolojileri bu imkanı sağlayabilmektedir. Bu sayede denetim elemanları mükelleflerin bilgisayar sistemlerine uzaktan bağlanarak veya mükelleflerin e-defterlerini uzaktan bağlantı yolu ile kendi bilgisayarlarına indirerek gerekli inceleme ve denetim süreçlerini gerçekleştirebilmektedir. Böylelikle hem denetim elemanlarının, bir zorunluluk oluşmadığı sürece mükelleflerin iş yerlerine gitmelerine gerek kalmayacağ gibi, mükelleflerin de edefterlerini fiziksel olarak denetim elemanlarına götürme zorunluluğu ortadan kalkacaktır. Ayrıca denetim elemanlarının, inceleme için gerekli olan bilgilere çok daha hızlı erişimleri sağlanacağından dolayı, mükelleflerin vergi incelemesi konusunda sürekli olarak denetim elemanlarına bilgi hazırlamalarına da gerek kalmayacaktır (Doğan, 2013: 345). 


\subsection{Elektronik Arşiv}

E-arşiv yönetimi, işletme faaliyetleri hakkındaki alınan ve korunan kanıtlar için gerekli süreçleri içeren oluşturma, işleme, muhafaza, kullanım ve elden çıkarılmasının verimliliği ve sistematik kontrolü anlamına gelir. Basılı arşivler gibi, e-arşiv yönetimi de genel arşivler içerisindeki kavramsal boşlukları önlemek için önemlidir. E-arşiv sistemlerinin, gerektiğinde kolaylıkla erişebilir bir şekilde oluşturulması ve muhafaza edilmesi gerekmektedir. İşletmeler açısından etkili e-arşiv yönetimi, açık, anlaşılır ve hesaplanabilir olmak için önemlidir (Moloi ve Mutula, 2007: 290).

E-arşiv uygulaması kapsamında oluşturulan belgeler Gelir İdaresi Başkanlığı'na bildirilen bilgi işlem sisteminde veya özel entegratör sisteminde oluşturulmalıdır. Kullanılan e-belgelerin biçimi üzerinde mali mühür veya nitelikli e-imza taşımaya, doğrulamaya, görüntülemeye ve kağıt baskı almaya imkan veren genel tanınırlığa sahip bir biçim olmalıdır. Uygulamayı kendi sistemi üzerinden kullanan tüzel kişiler, elektronik ortamda oluşturdukları kendi faturalarını kendi mali mühürleri ile, gerçek kişiler ise kendi mali mühürleri veya nitelikli e-imzaları ile onaylarlar. Uygulamanın özel entegratör aracılığı ile kullanılması durumunda ise belgeler, mükelleflerin mali mühürleri veya nitelikli e-imzaları ile veya mükellefin istemesi halinde özel entegratörün mali mührü ile onaylanması gerekmektedir. Earşiv uygulaması kapsamında oluşturulan belgeler 433 No'lu VUK Genel Tebliği ile getirilen düzenlemeler dişında başta Vergi Usul Kanunu olmak üzere diğer vergi kanunları ve ilgili düzenlemelerde yer alan sürelere ve belirlenen şartlara uygun biçimde oluşturulmaları gerekmektedir (433 No'lu VUK Genel Tebliği, 2013: 6).

\subsection{Elektronik Beyanname}

Maliye Bakanlığı, mükelleflerin vergi ödeme konusundaki ödevlerini yerine getirmede, bilgi ve iletişim teknolojilerindeki gelişmelerden yararlanmak, vergi beyannameleri ile bildirim ve eklerinin kolay, hızlı, ekonomik ve güvenli bir şekilde vergi dairesine ulaşmasını sağlamak, beyannamelerin doldurulmaları sırasında oluşacak olası hataları ve mükellef mağduriyetlerini en aza indirmek, vergi dairelerindeki kabul, tarih, tahakkuk gibi iş ve işlemleri azaltarak kolaylık sağlamak ve mükelleflere daha iyi hizmet vermek amacıyla 340 Sıra No'lu VUK Genel Tebliği ile e-beyanname uygulamasını başlatmıştır (Bakmaz, 2007: 199-200).

E-beyanname uygulamasını kullanacak olan herkesin, bir seferliğe mahsus olmak üzere vergi dairesine giderek, e-beyanname uygulamasına kaydını yaptırıp kullanıcı kodu, şifre ve parola bilgilerini alması gerekmektedir. Kayıt gerçekleştikten sonra mükellefler ebeyanname uygulaması için kullanacakları yazılımı Gelir İdaresi Başkanlığının web sitesinden ücretsiz olarak temin edebilirler. Hazırlanan beyannamelerin gönderilebilmesi için, mükelleflerin internet bağlantısı aracılığı ile Gelir İdaresi Başkanlığı İnternet Vergi Dairesine, aldıkları kullanıcı kodu, şifre ve parola bilgilerini kullanarak bağlanmaları gerekmektedir. 
Giriş yapıldıktan sonra bilgisayarda hazırlanmış olan beyannameler sistem üzerinden paketlenerek Gelir İdaresi Başkanlığına gönderilir. Eğer gönderilen beyannamelerde hata varsa, yapılan kontrolün hemen ardından tespit edilen hatalar yine elektronik olarak mükellefe bildirilir ve hatalar düzeltildikten sonra tekrar gönderilmeleri istenir. Hata yoksa beyannameler sistemde mükellefe gösterilerek onay vermesi istenir. Gönderilen beyannameler onaylandığ edilmiş sayılır. Kullanıcı yapılan işlemi gösteren tahakkuk fişini burada ekrandan temin edebilir ve ayrıca pdf biçiminde kendi bilgisayarına kaydedip saklayabilir (Turan ve Özgen, 2009: 137-138).

\subsection{Elektronik Tebligat}

E-tebligat, 213 Sayılı Vergi Usul Kanun ile 456 Sira No’lu VUK Genel Tebliği hükümlerine göre tebliği gereken e-tebligat uygulaması ile mükelleflerin elektronik posta adreslerine tebliğ edilmesidir. E-tebligat, fiziksel ortamda yapılacak olan tebliğ ile aynı sonucu doğurmaktadır (http://www.gib.gov.tr/e-Tebligat: 2016). Ayrıca, 456 Sıra No'lu VUK Genel Tebliği (2015: 2)' ne göre e-tebligat, 213 Sayılı Kanun hükümlerine göre tebliği gereken evrakın e-tebligat sistemi ile muhattapların e-posta adreslerine tebliğ edilmesi olarak tanımlanmıştır.

E-tebligat, vergi borcu bulunan mükellefelere yönelik olarak etkin bir şekilde kullanılması planlanan bir uygulamadır. E-tebligat uygulamasının kullanılmaya başlanması ile birlikte Maliye Bakanlığı tarafından eski usulde yapılan tebliğ işlemlerinde yaşanan sıkıntıların aşılması ve mükelleflere en kısa sürede e-posta adreslerini kullanarak tebligat yapılması amaçlanmaktadır. Bunun için mükelleflerin bağlı bulundukları vergi dairesine başvurarak e-tebligat süreçlerini başlatmaları gerekmektedir (Ay vd., 2016: 18).

Vergi Usul Kanunu hükümlerine göre, tebliğ içerisinde değerlendirilen bilgi ve belgeler içerisinde kabul edilen tüm evraklar elektronik ortam üzerinden ilgili mükelleflere iletilmektedir. Tebliğde yer alan bilgi ve belgeler, e-imza ile imzalanmış bir şekilde karşı tarafın e-posta adresine gönderilmektedir. Gerek e-tebligata ilişkin başvurularda, gerekse etebligat gönderildiğinde mükellef, e-tebligat talep formunda belirttiği telefon numarası vasitası ile mesaj olarak veya e-posta adresine posta olarak bilgilendirme yapilacaktır. Mükellefler, vergi dairesine yaptıkları başvuru sonrasında aldıkları giriş bilgileri ile internet vergi dairesinin sisteminden giriş yapacaklar ve e-tebligat adreslerine ulaşacaklardır. Giriş bilgilerine sahip olmayanlar ise, her seferinde gerçekleştirilecek kimlik bilgilerinin kontrolünden sonra e-tebligat adreslerine ulaşabileceklerdir. E-imzalı evrak, mükellefin eposta adresine ulaştığı beşinci günün sonunda tebliğ edilmiş sayılacaktır. Ayrıca bu kayıtların otuz yıl boyunca, zaman bilgilerini de kapsayacak biçimde arşivde saklanmaları gerekmektedir (Arslan ve Biniş, 2016: 309). 


\section{ARAŞTIRMANIN TANITIMI}

Son yıllarda Maliye Bakanlığı tarafından gerçekleştirilen yenilikler ile hayata giren ebelge sistemlerinin, muhasebe meslek mensupları açısından ne denli kabullenildiğinin ölçülebilmesi için, Karabük İlinde bulunan muhasebe meslek mensuplarına veri toplama aracı uygulanmış ve gerekli analizler yapılarak sonuçları yorumlanmıştır.

\subsection{Araştırmanın Alanı}

Araştırma evrenini muhasebe meslek mensupları, ana kütlesini ise Karabük İlindeki serbest muhasebeci mali müşavirler (SMMM) oluşturmaktadır. Söz konusu ana kütle içerisinde 170 adet SMMM ile irtibata geçilmeye çalışılmış ancak, bunların 122 tanesinden olumlu geri dönüş alınarak hazırlanan veri toplama aracı uygulanmıştır. Geri dönüş oranı $\% 71,2$ olarak belirlenmiştir.

\subsection{Araştırmanın Önemi ve Amacı}

Günümüz işletmelerinin, bilgi ve iletişim teknolojilerini hemen her alanda kullanmaya ve bu teknolojiden en üst seviyede fayda sağlamaya çalıştıkları görülmektedir. Muhasebe birimleri bütün bu gelişmelerden diğer birimlere göre çok daha önce etkilenmiştir. Bilgilerin kaydedilmesi, saklanması, yorumlanması ve analiz edilmesi konusunda uzun y1llardan beri bilgi ve iletişim teknolojilerinden faydalanılmaktadır. Bu gelişmeler sayesinde özellikle muhasebe birimlerindeki işlerin çok daha kolay ve hızlı gerçekleştirilmesi sağlanmıştır. Ancak bu gelişmeler dahi işletmeleri kağıt belge kullanımından kurtaramamıştır. Son yıllarda yasal olarak atılan adımlar ile hayata geçirilen e-belge çeşitlerinin kullanımı ile işletmelerde kağıt belge kullanım oranı azalmaya başlamıştır. Ayrıca muhasebe süreçlerinin denetiminin eskiye göre daha sağlıklı yapılabilmesi konusunda önemli adımların atılmasını sağlamıştır. Faaliyetlerin bilgisayar tabanlı ortamlarda yürütülmesi, sonuçlarının alınarak elektronik olarak belgelerde saklanması ve gerekli yerlere iletilmesi sonucunda, sistemin sürekli olarak kontrol altında tutulabilmesi ve ayrıca usulsüz işlemlerin önüne geçilebilmesi hedeflenmektedir. Araştırma, Karabük İlindeki muhasebe meslek mensuplarının e-belge sistemlerini kullanma ve kabullenme düzeylerini ortaya koymayı amaçlamaktadır.

\subsection{Metodoloji}

Çalışmanın araştırılabilmesi için muhasebe meslek mensuplarına uygulanacak olan veri toplama arac1, teknoloji sistemlerinin kabulünün ölçülmesi amaciyla Venkatesh ve diğerleri (2003) tarafından oluşturulmuş ve sonrasında bir çok kez çeşitli araştırmalarda kullanılmış olan "Birleştirilmiş Teknoloji Kullanım ve Kabullenme Teorisi”" (BTKKT) kapsamında hazırlanmış olan veri toplama aracı sisteminden elde edilmiştir. 


\subsubsection{Birleştirilmiş Teknoloji Kullanım ve Kabullenme Teorisi}

Venkatesh vd.(2003) yaptıkları bir çalışma ile teknolojinin kullanıcılar tarafindan kabullenmesine yönelik daha önceleri oluşturulmuş 8 adet modelin (planlı davranış kuramı, sebepli davranış kuramı, teknoloji kabul modeli, güdülenme modeli, bilgisayar kullanım modeli, birleştirilmiş teknoloji kabul ve planlı davranış kuramı, yeniliğin yayılması kuramı ve sosyal bilişsel kuramı) avantajlı yanlarından faydalanarak ortaya birleşik yeni bir model çıkartmışlardır. Geliştirilen bu yeni modelin kapsadığı ana araştırma konuları, performans beklentileri, çaba beklentileri, sosyal etki, kolaylaştırma koşulları olarak sıralanmaktadır. Bu araştırma konularından performans beklentisi, çaba beklentisi ve sosyal etki, teknolojik gelişim karşısındaki davranışsal niyetin üzerinden dolaylı olarak, kolaylaştırma koşulları ise doğrudan kullanma niyetini etkileyen faktörler olarak tespit edilmişlerdir (Uğur ve Türkmen, 2014: 573-574).

- Performans Beklentisi: Kullanıcının teknolojik gelişmeyi kullanması durumunda kendisine olumlu yönde fayda sağlayacağına inanma derecesi olarak ifade edilmektedir (Venkatesh vd., 2003: 447).

- Çaba Beklentisi: Teknolojik gelişmeyi kullanmanın iş süreçlerini daha da kolaylaştıracağına dair inanç derecesi olarak belirtilmektedir (Venkatesh vd., 2003: 450).

- Sosyal Etki: Kullanıcıların sistemi kullanma kararı almaları konusunda, sektörde başkaları tarafından da kullanılıp kullanılmadığına verdikleri önem derecesidir. Teknolojik gelişmenin kullanımının ilk zamanlarında önem verilen bir etken olmasına karşın, kullanıcılar tarafından sistemin kullanımına alışkanlık kazanıldıkça önemini yitirdiği ifade edilmektedir (Venkatesh vd., 2003: 451).

- Kolaylaştırma Koşulları: Kullanıcının uygulanacak teknolojik gelişmeyi kullanmasına katkı sağlayacak alt yapı sistemlerinin yeterli seviyede olduğuna dair inancının ölçülmesi olarak belirtilmiştir (Venkatesh vd., 2003: 453).

Venkatesh vd. (2003) tarafından hazırlanmış BTKKT modeli, bilgi ve iletişim teknolojilerindeki gelişmelere karşı gösterilen uyumu, gönüllülük esasına dayanan eğlence ve telekomünikasyon kullanımı ve zorunluluk esasına dayanan banka ve kamu idaresi gibi 4 alanda test etmişlerdir. Gerçekleştirilen bu test sonucunda, bilgi ve iletişim teknolojilerindeki yaşanan gelişmelere gösterilen uyum derecesi \%70 olarak tespit edilmiştir. Ayrıca daha öncelerde yapılan araştırmalarda göz ardı edilmiş olan yaş, cinsiyet, deneyim ve gönüllülük gibi araçların da teknoloji uyumu konusunda son derece önemli olduğu kanısına varmışlardır (Demirbaş vd., 2012: 67-68).

Schaupp vd. (2010), BTKKT modeli üzerine ABD'de e-beyanname veren kişilerin kullanma niyetlerini ortaya koyan bir çalışma yürütmüşlerdir. Yaptıkları bu araştırmanın sonuçlarına göre BTKKT modelinde bulunan değişkenlere ek olarak "güven beklentileri" ve 
"risk algısı" değişkenlerinin de kullanma niyetini etkilediklerini tespit etmişler ve BTKKT' ye bütünleşik bir model ortaya çıkartmışlardır (Schaupp vd., 2010: 636-644).

\subsection{Araştırmanın Hipotezleri}

H1. Karabük ilindeki muhasebe meslek mensuplarının e-belge sistemine ilişkin performans beklentileri, davranışsal tutum üzerine pozitif etkiye sahiptir.

H2. Karabük ilindeki muhasebe meslek mensuplarının e-belge sistemine ilişkin çaba beklentileri, davranışsal tutum üzerine pozitif etkiye sahiptir.

H3. Karabük ilindeki muhasebe meslek mensuplarının e-belge sistemine ilişkin sosyal etkileri, davranışsal tutum üzerine pozitif etkiye sahiptir.

H4. Karabük ilindeki muhasebe meslek mensuplarının e-belge sistemine ilişkin güven beklentileri, davranışsal tutum üzerine pozitif etkiye sahiptir.

H5. Karabük ilindeki muhasebe meslek mensuplarının e-belge sistemine ilişkin kolaylaştırma koşulları, kullanma niyeti üzerine pozitif etkiye sahiptir.

H6. Karabük ilindeki muhasebe meslek mensuplarının e-belge sistemine ilişkin davranışsal tutumları, kullanma niyeti üzerine pozitif etkiye sahiptir.

\subsection{Verilerin Analizi}

Araştırma için uygulanmış olan veri toplama aracı ile toplanan verilerin analizi için SPSS v20.0 programı kullanılarak ilişkisel tarama modeli uygulanmıştır. Programa girilen verilerin, frekans, yüzde, aritmetik ortalama, güvenilirlik katsayısı, normallik testi, korelasyon katsayısı, basit doğrusal regresyon testi sonuçları incelenmiştir.

Uygulanan veri toplama aracının güvenilirlik katsayısı testi sonucunda Cronbach's Alpha değeri 0,893 olarak hesaplanmıştır. $\mathrm{Bu}$ değer, araştırmanın güvenilirliğinin yüksek olduğunu göstermektedir.

Verilerin veri toplama aracı içerisindeki gruplarının aritmetik ortalamaları alınarak gerekli yorumlamalar yapılmıştır. Araştırma verilerinin analiz edilmesi konusunda uygulanan model Şekil 1' de görülmektedir. Uygulanan veri toplama aracının likert ölçeğindeki dereceleme maddeleri, "Kesinlikle Katılmıyorum", “Katılmıyorum", “Kararsızım”, "Katılıyorum”, “Tamamen Katılıyorum” şeklinde oluşturulmuştur. 
Şekil 1. Araştırmanın Modeli

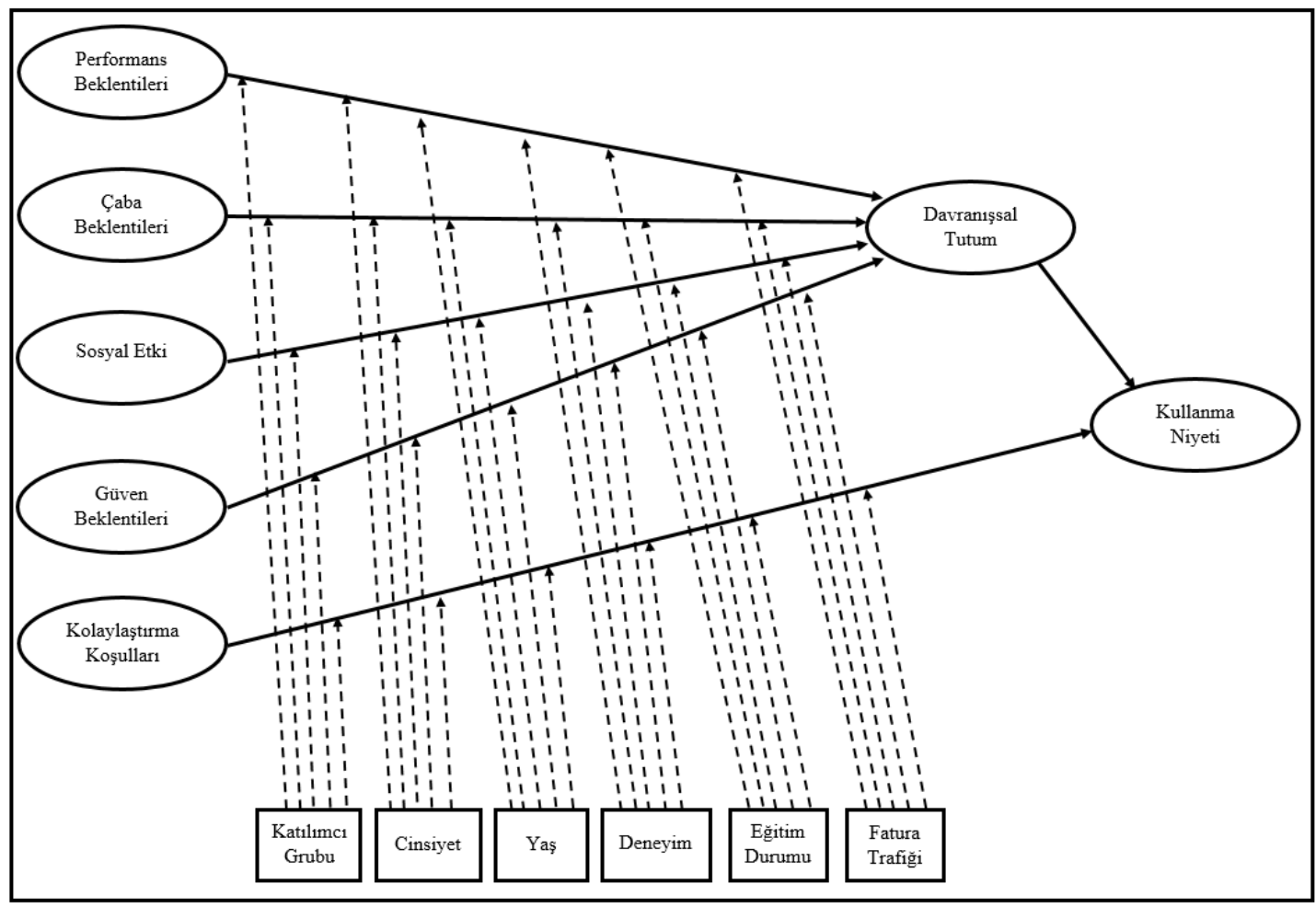

Veri toplama aracı vasıtası ile elde edilen verilerin, oluşturulan hipotezler doğrultusunda normallik testleri yapılarak, daha sonra parametrik veya parametrik olmayan testlerin kullanılması konusunda gerekli tercihin yapılması sağlanmıştır.

Dağılımların normal olup olmadığına karar verilebilmesi için çarpıklık ve basıklık değerlerinin kendi standart hata değerleri ile oranlanmaları (Örn: çarpıklık / çarpıklık std. hata) ve bu oran sonucunda çıkan sonucun ele alınması gerekmektedir. Elde edilen bu değere $\mathrm{Z}$ değeri adı verilmektedir. Bir dağılımın normal olarak nitelendirilebilmesi için hem çarpıklık, hem de basıklık için elde edilen $Z$ değerlerinin -1,96 ile $+1,96$ değerleri arasında olması gerekmektedir. Bu sınırlar dahilinde alınacak sonuç, dağılımın normal olduğunu ve analiz için parametrik testlerin kullanılabileceğini ifade etmektedir. Ĕger Z skorlarından biri belirtilen sınırlar dahilinde çıkmazsa, analiz işleminde parametrik olmayan testlerin kullanılması gerekecektir (Cramer ve Howitt, 2004: 157-159).

Ana hipotezlerin yorumlanmasında "Spearman Korelasyon Testi ve Basit Doğrusal Regresyon Analizi” yöntemleri kullanılmıştır. Korelasyon analizi ile 2 değişken arasındaki ilişkinin mevcut olup olmadığını ve ilişki varsa derecesinin hesaplanması amaçlanmıştır. Korelasyon analizi, bağımsız değişkende gerçekleşen bir değişimin bağımlı değişkeni hangi yönde nasıl etkilediğini göstermek için kullanılmaktadır (Kalaycı, 2009: 115). Regresyon analizi, bir bağımsız değişkenin, bağımlı bir değişken üzerine etkisini tespit etmek için kullanılan bir analiz yöntemidir. Araştırmamızda bir bağımlı ve bir bağımsız değişkenler arası analizler gerçekleştirildiğinden ve korelasyon analizi sonuçları doğrusal çıktığından dolayı basit doğrusal regresyon analizi yapılmıştır. Basit regresyon analizinde, bağımlı değişkendeki 
değişim miktarının, regresyon modelinde kullanılan bağımsız değişken ile ne ölçüde ifade edildiğini göstermek amacıyla kullanılmaktadır. Korelasyon analizi sonucunda değişkenler arası doğrusal ilişki mevcutsa basit doğrusal regresyon analizi, doğrusal ilişki yoksa basit doğrusal olmayan regresyon analizi kullanılmaktadır (Gürbüz ve Şahin, 2014: 260-262).

\subsection{Katılımcıların Demografik Özellikleri}

Karabük ilinde araştırmaya katılan muhasebe meslek mensuplarının demografik özellikleri, kullanıcı grubu, cinsiyet, yaş, eğitim durumu ve mesleki deneyim başlıklarının ifade edildiği genel bilgiler Tablo 1'de gösterilmektedir.

Tablo 1. Katılımcıların Demografik Özellikleri

\begin{tabular}{|c|c|c|c|c|}
\hline Değișken & Gruplar & Frekans & Yüzde & Kümülatif Yüzde \\
\hline \multirow{3}{*}{ Katılımcı Grubu } & $\begin{array}{l}\text { E-Fatura \& E- } \\
\text { Defter Mükellefine } \\
\text { Sahip Olmayan } \\
\text { Muhasebe Meslek } \\
\text { Mensupları }\end{array}$ & 56 & 45,9 & 45,9 \\
\hline & $\begin{array}{l}\text { E-Fatura \& E- } \\
\text { Defter Mükellefine } \\
\text { Sahip Olan } \\
\text { Muhasebe Meslek } \\
\text { Mensupları }\end{array}$ & 66 & 54,1 & 100,0 \\
\hline & TOPLAM & 122 & 100,0 & \\
\hline \multirow{3}{*}{ Cinsiyet } & Kadın & 18 & 14,8 & 14,8 \\
\hline & Erkek & 104 & 85,2 & 100,0 \\
\hline & TOPLAM & 122 & 100,0 & \\
\hline \multirow{5}{*}{ Yaş } & 30 ve daha az & 12 & 9,8 & 9,8 \\
\hline & $31-40$ & 40 & 32,8 & 42,6 \\
\hline & $41-50$ & 50 & 41,0 & 83,6 \\
\hline & $51+$ & 20 & 16,4 & 100,0 \\
\hline & TOPLAM & 122 & 100,0 & \\
\hline \multirow{5}{*}{ Eğitim Durumu } & Lise ve daha az & 15 & 12,3 & 12,3 \\
\hline & Önlisans & 10 & 8,2 & 20,5 \\
\hline & Lisans & 93 & 76,2 & 96,7 \\
\hline & Lisansüstü & 4 & 3,3 & 100,0 \\
\hline & TOPLAM & 122 & 100,0 & \\
\hline \multirow{6}{*}{ Mesleki Deneyim } & 5 y1l ve daha az & 10 & 8,2 & 8,2 \\
\hline & 6-10 y1l aras1 & 11 & 9,0 & 17,2 \\
\hline & 11-15 y1l aras1 & 27 & 22,1 & 39,3 \\
\hline & $16-20$ y1l aras1 & 31 & 25,4 & 64,8 \\
\hline & 21 y1l ve üstü & 43 & 35,2 & 100,0 \\
\hline & TOPLAM & 122 & 100,0 & \\
\hline
\end{tabular}


Tablo 1'deki verilere göre, e-fatura ve e-defter kullanımının \%54,1 oranına ulaştığ görülmektedir. Meslek mensuplarının cinsiyet dağılımlarına bakıldığında, SMMM mesleğinde \%85,2 gibi büyük bir kısmın erkeklerden oluştuğu görülmektedir. Meslek mensupları arasında 41 yaş ve üzeri olanların \%57,4 seviyesinde bir orana sahip olduğu gözlenebilmektedir. Meslek mensupları, eğitim durumları olarak gruplandırıldı̆̆ında ise \%76,2 seviyesinde lisans mezunu oldukları görülmektedir. Mesleki deneyim konusunda ise meslek mensuplarının \%60,6 oranında en az 16 yıllık mesleki tecrübeye sahip oldukları görülmektedir.

Tablo 2'de katılımcıların kullandıkları e-belge türlerinin kullanım oranları gösterilmektedir.

Tablo 2. E-Belge Kullanım Oranlarına Ait Bilgiler

\begin{tabular}{|l|c|c|}
\hline E-Belge Türü & Frekans & Yüzde \\
\hline E-Fatura & 66 & 54,10 \\
\hline E-Defter & 66 & 54,10 \\
\hline E-Arşiv & 31 & 25,40 \\
\hline E-Beyanname & 122 & 100 \\
\hline E-Tebligat & 121 & 99,18 \\
\hline
\end{tabular}

Tablo 2'de bulunan verilere göre, özellikle e-belge sistemi içerisinde var olan yasal düzenlemelerden dolayı e-fatura ve e-defter sistemlerinin kullanım oranları $\% 54,10$ seviyesine ulaştı̆g 1 görülmektedir. E-arşiv sistemi, yeni bir sistem olup, \%25,40 kullanım oranına sahip olduğu görülmektedir. E-beyannamenin artık tamamen sisteme yerleştiği ve \%100 oranında kullanımının bulunduğu görülmektedir. E-tebligat sisteminin ise, e-arşiv gibi yeni bir sistem olmasına karşın \%99,18'lik kullanım oranına ulaştığı görülmektedir.

\subsection{Fonksiyonel Bilgilere İlişkin Bulgular}

Muhasebe meslek mensupları tarafindan, veri toplama aracında bulunan 39 soruya verdikleri cevaplar doğrultusunda elde edilmiş olan veriler, ilişkisel tarama modeli doğrultusunda analiz edilerek sonuçları yorumlanmıştır. 
Şekil 2. Fonksiyonel Bilgilere İlişkin Bulgular

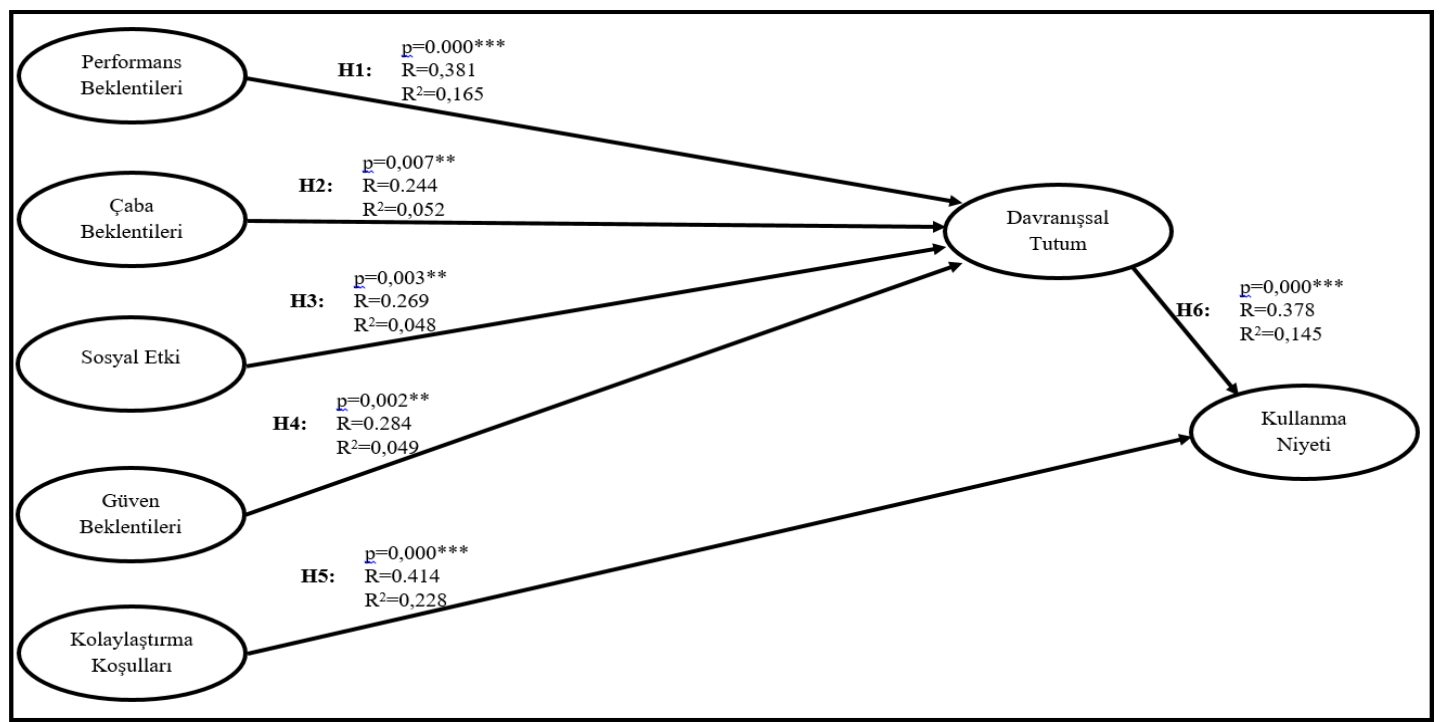

Tablo 3. Hipotezlere İlişkin Sonuçlar

\begin{tabular}{|c|c|c|c|c|c|c|c|c|}
\hline Hipotez & Başlıklar & Ortalamalar & Çarpıklık(Z) & Basıklık(Z) & $\mathbf{p}$ & $\mathbf{R}$ & Adj. $\mathbf{R}^{2}$ & Sonuç \\
\hline \multirow{2}{*}{ H1 } & $\begin{array}{l}\text { Performans } \\
\text { Beklentileri }\end{array}$ & 3,5697 & $-2,561$ & 0,556 & \multirow{2}{*}{$0.000 * * *$} & \multirow{2}{*}{0.381} & \multirow{2}{*}{0.165} & \multirow{2}{*}{ Kabul } \\
\hline & $\begin{array}{l}\text { Davranışsal } \\
\text { Tutum }\end{array}$ & 3,2508 & $-2,224$ & 2,106 & & & & \\
\hline \multirow{2}{*}{$\mathrm{H} 2$} & $\begin{array}{l}\text { Çaba } \\
\text { Beklentileri }\end{array}$ & 3,5279 & $-2,114$ & 1,005 & \multirow{2}{*}{$0.007 * *$} & \multirow{2}{*}{0.244} & \multirow{2}{*}{0.052} & \multirow{2}{*}{ Kabul } \\
\hline & $\begin{array}{l}\text { Davranışsal } \\
\text { Tutum }\end{array}$ & 3,2508 & $-2,224$ & 2,106 & & & & \\
\hline \multirow[b]{2}{*}{$\mathrm{H} 3$} & Sosyal Etki & 3,4611 & $-1,425$ & $-0,411$ & \multirow[b]{2}{*}{$0,003 * *$} & \multirow[b]{2}{*}{0,269} & \multirow[b]{2}{*}{0,048} & \multirow[b]{2}{*}{ Kabul } \\
\hline & $\begin{array}{l}\text { Davranışsal } \\
\text { Tutum }\end{array}$ & 3,2508 & $-2,224$ & 2,106 & & & & \\
\hline \multirow{2}{*}{$\mathrm{H} 4$} & $\begin{array}{l}\text { Güven } \\
\text { Beklentileri }\end{array}$ & 3,5020 & 0,224 & 0,177 & \multirow{2}{*}{$0,002 * *$} & \multirow{2}{*}{0,284} & \multirow{2}{*}{0,049} & \multirow{2}{*}{ Kabul } \\
\hline & $\begin{array}{l}\text { Davranışsal } \\
\text { Tutum }\end{array}$ & 3,2508 & $-2,224$ & 2,106 & & & & \\
\hline \multirow{2}{*}{ H5 } & $\begin{array}{l}\text { Kolaylaştırma } \\
\text { Koşulları }\end{array}$ & 3,5806 & $-6,137$ & 5,536 & \multirow{2}{*}{$0,000 * * *$} & \multirow{2}{*}{0,414} & \multirow{2}{*}{0,228} & \multirow{2}{*}{ Kabul } \\
\hline & $\begin{array}{l}\text { Kullanma } \\
\text { Niyeti }\end{array}$ & 3,7689 & $-2,534$ & 0,726 & & & & \\
\hline \multirow{2}{*}{ H6 } & $\begin{array}{l}\text { Davranışsal } \\
\text { Tutum }\end{array}$ & 3,2508 & $-2,224$ & 2,106 & \multirow{2}{*}{$0,000 * * *$} & \multirow{2}{*}{0,378} & \multirow{2}{*}{0,145} & \multirow{2}{*}{ Kabul } \\
\hline & $\begin{array}{l}\text { Kullanma } \\
\text { Niyeti }\end{array}$ & 3,7689 & $-2,534$ & 0,726 & & & & \\
\hline
\end{tabular}


Tablo 3'te gösterilen verilere göre, tüm hipotezlerde, normal dağılıma sahip olmayan veriler bulunduğundan dolayı, başlıklar arası ilişkilerin analizinde parametrik olmayan "Spearman Korelasyon Analizi” kullanılmıştır. Uygulanan korelasyon analizi (R) sonuçlarına göre hipotezlerin tamamı, başlıkları arasında olumlu ilişkilere sahip oldukları görülmüştür. Ayrıca hipotezlerdeki başlıklar arasında gerçekleştirilen basit doğrusal regresyon analizi kapsamında (Adj. $\mathrm{R}^{2}$ ) performans beklentileri, çaba beklentileri, sosyal etki ve güven beklentilerinin davranışsal tutumlarına ait varyansı, kolaylaştırma koşulları ve davranışsal tutumlarının ise kullanma niyetlerine ait varyansı açıkladıkları tespit edilmiştir. Elde edilen bu sonuçlar 1şığında ortaya konmuş olan hipotezlerin tamamı kabul edilmiştir.

\section{DEĞERLENDİRME VE SONUÇ}

Muhasebe meslek mensuplarının kullandıkları e-belge teknolojilerinin benimsenme durumunun incelenmesi amacıyla oluşturulmuş olan bu çalışma, Venkatesh vd. (2003) tarafindan oluşturulmuş olan birleştirilmiş teknoloji kullanımı kabullenme teorisi(BTKKT) referans alınarak tasarlanmıştır. $\mathrm{Bu}$ şekilde katılımcıların, performans beklentileri, çaba beklentileri, kolaylaştırma koşulları ve sosyal etki derecelerinin, davranışsal tutum ve kullanma niyeti derecelerini ne denli etkiledikleri tespit edilmeye çalışılmıştır. Ayrıca Schaupp ve diğerleri (2010) tarafından e-beyanname üzerine yapılan bir çalışma ile BTKKT modeline ekledikleri "Güven Beklentileri” ve "Risk Algısı” başlıkları da, bu çalışmada "Güven Beklentileri" başlığı altında birleştirilerek, davranışsal tutum ve kullanım niyetini ne derecede etkiledikleri belirlenmeye çalışılmıştır. Çalışmada ilişkisel tarama modeli kullanılmış olup, çalışmanın ana kütlesini Karabük İlinde faaliyette bulunan 170 muhasebe meslek mensubu oluşturmaktadır. Veri toplama kısmında veri toplama aracı çalışması düzenlenmiş olup, araştırma ana kütlesini oluşturan muhasebe meslek mensuplarından \%71,2 oranında geçerli geri dönüş sağlanmıştır.

Araştırmada elde edilen verilerin analizi sonucunda ulaşılan sonuçlara göre, e-fatura ve e-defter sistemlerinin kullanım oranının \%50 seviyesinin üzerine çıktığı görülmüştür. Maliye Bakanlığı tarafindan uygulanan yasal düzenlemeler aracılığı ile bu oranın önemli derecede arttığı ve önümüzdeki yıllarda yapılması planlanan yeni düzenlemeler ile daha da artacağı söylenebilmektedir.

Muhasebe meslek mensuplarının e-belge sistemlerine ilişkin performans beklentilerinin, çaba beklentilerinin, sosyal etkilerinin ve güven beklentilerinin, davranışsal tutumları ile anlamlı pozitif bir ilişkiye sahip oldukları görülmüştür. Ayrıca ilgili değişkenlerin e-belge sistemlerine yönelik davranışsal tutumlarına ait varyans üzerinde açıklayıcılık özelliği olduğu görülmüştür. Bunun yanında kolaylaştırma koşullarının ve davranışsal tutumlarının, kullanma niyetleri ile anlamlı pozitif bir ilişkiye sahip oldukları ve bu değişkenlerin e-belge sistemlerine yönelik kullanma niyetlerine ait varyans üzerinde açıklayıc1lık özelliği olduğu tespit edilmiştir. 
Katılımcıların doldurdukları veri toplama aracı sonuçlarının ortalamalarına bakıldığında genel olarak "Kararsız" ve "Katılıyorum" derecelerinin ortalarında kaldıkları görülmektedir. $\mathrm{Bu}$ durum sistemin kabullenme seviyesinin orta derecelerde kaldığını göstermektedir. Ayrıca katılımcılar ile yapılan görüşmelerde bilgi ve iletişim teknolojileri üzerinde kurulan e-belge sistemlerinin kullanımına geçiş konusunda yasal zorunluluktan başlandğ 1 , isteğe bağlı geçişlerin artırılabilmesi için daha fazla teşvik verilmesinin gerektiğini ve sistemlerin ilk kurulum maliyetlerinin çok yüksek olduğu ve bunun makul bir düzeye çekilmesi gerektiği belirtilmiştir. Ek olarak bilgi güvenliği konusunda da şüpheleri bulunan katılımcıların bu konuda da yeterli garanti ve teknik desteğin sağlanması durumunda kullanım oranının pozitif etkileneceği ifade edilmiştir.

$\mathrm{Bu}$ araştırma Karabük İli’ndeki muhasebe meslek mensuplarının e-belge sistemlerini benimseme durumlarını ölçmek için yapılmıştır. Benzer şekilde, özellikle son yıllarda yayılım gösteren e-fatura, e-defter ve e-arşiv sistemlerini şu anda kullanmakta olan kurum yöneticilerinin de ilgili sistemler hakkında düşüncelerini ölçmek amacıyla çalışma güncellenebilir.

\section{KAYNAKLAR}

Acar, V., \& Öksüz, Ö. (2013). Finansal Bilgilerin Elektronik Ortamda Paylaşımı ve E-Defter Uygulamaları. Akademik Araştırmalar ve Çalışmalar Dergisi, 5(8), 62-89.

Arslan, M., \& Biniş, M. (2016). Türk Vergi Sisteminde Tebligat ve Elektronik Tebligat. Yönetim ve Ekonımi Araştırmaları Dergisi, 14(1), 300-317.

Ay, H., Alpaslan, M., \& Kaya, E. (2016). Vergi Uygulamalarında E-Tebligat ve E-Haciz. Ankara: Seçkin Yayıncılık.

Bakmaz, Z. (2007). Son Düzenlemeler Işığında Tüm Yönleriyle E-Beyanname Uygulaması. Mali Çözüm Dergisi(83), 199-210.

Bensghir, T. K. (1996). Bilgi Teknolojileri ve Örgütsel Değişim. Ankara: Türkiye ve Orta Doğru Amme İdaresi Yayını.

Björk, B.-C. (2003). Electronic Document Management in Construction: Research Issues and Results. ITcon, 8, 105-117.

Burtylev, I. N., Mokhun, K. V., Bodnya, Y. V., \& Yukhnevich, D. N. (2013). Development of Electronic Document System: Advantage and Efficiency. Science and Technology(Special Issue), 1-9.

Combe, C. (2006). Introduction To E-Business Management And Strategy. Burlington,: Oxford: Elsevier. 
Cramer, D., \& Howitt, D. (2004). The SAGE Dictionary of Statistics. Wiltshire: Cromwell Press Ltd.

Demirbaş, T., Gerçek, A., Giray, F., Yüce, M., \& Oğuzlar, A. (2012). MÜKELLEFLERİN EVERGILEME SISTEMINİ BENIMSEMELERİNI ETKILLEYEN FAKTÖRLERIN ANALIZİ: BURSA ARAŞTIRMASI. Uludağ Üniversitesi İktisadi ve İdari Bilimler Fakültesi Dergisi, 16(1), 59-84.

Dinç, E., \& Varıcı, İ. (2008). E-İşletme Olgusunun Muhasebe İlke ve Uygulamaları Üzerine Etkisi. Sosyal Bilimler Dergisi, 10(1), 191-211.

Doğan, U. (2013). 550 Soruda E-Fatura E-Defter. Seçkin Yayıncılık.

Ermiş, K. (2006). Sayısal İmza ve Elektronik Belge Yönetimi. Bilgi Dünyası, 7(1), 121-146.

http://www.efatura.gov.tr/efaturahakkinda.html, 10 Temmuz 2015

http://www.gib.gov.tr/e-Tebligat, 5 Temmuz 2016

Gürbüz, S., \& Şahin, F. (2014). Sosyal Bilimlerde Araştırma Yöntemleri. Ankara: Seçkin Yayınc1l1k.

Kalaycı, Ş. (2009). SPSS Uygulamalı Çok Değişkenli İstatistik Teknikleri. Ankara: Öz Baran Ofset.

Karadeniz, S. (2012). Elektronik Defter ve Fatura Uygulaması. Vergi Dünyası Dergisi(366), 4-8.

Kumkale, R. (2013). Bütün Yönleri İle E-Fatura \& E-Defter. Ankara: Seçkin Yayıncılık.

Laudon, K. J., \& Laudon, J. P. (2009). Essentials Of Management Information Sytems. 8th Edition. New Jersey: Printice Hall.

Maliye Bakanlığı. (2010, Mart 05). Vergi Usul Kanunu Genel Tebliği: Sıra No: 397. Ankara.

Maliye Bakanlığı. (2013, Aralık 30). Vergi Usul Kanunu Genel Tebliği: Sıra No: 433. Ankara.

Maliye Bakanlığı. (2015, 08 27). Vergi Usul Kanunu Genel Tebliği: Sira No. 456. Ankara.

Maliye Bakanlığı ve Gümrük Ticaret Bakanlığı. (2011, 12 13). Elektronik Defter Genel Tebliği: Sira No 1. Ankara.

Moloi, J., \& Mutula, S. (2007). E-Records Management In An E-Goverment Setting In Bostwana. Information Development, 23(4), 290-306.

Schaupp, L. C., Carter, L., \& McBride, M. E. (2010). E-File Adoption: A Study of U.S. Taxpayers' Intentions. Computers in Human Behavior, 26, 636-644.

Sevim, A. (2003). Dijital Girişimler. M. Şahin içinde, Yönetim Bilgi Sistemi (s. 59-87). Eskişehir: Anadolu Üniversitesi.

Tahirov, A. (2009). Bilgisayar Destekli Bilgi Sistemleri. Journal of Qafqaz University(27), 123-133. 
Turan, A. H., \& Özgen, F. B. (2009). Türkiye'de E-Beyanname Sisteminin Benimsenmesi: Geliştirilmiş Teknoloji Kabul Modeli İle Amprik Bir Çalışma. Doğuş Üniversitesi Dergisi, 10(1), 134-147.

Uğur, N. G., \& Türkmen, M. (2014). Tüketicilerin Mobil Uygulamaları Kabulüne Yönelik Bir Model Önerisi. Uluslararası Bilgi, Ekonomi ve Yönetim Kongresi Bildileri Kitabı, (s. 567-583). Antalya.

Uyar, S. (2006). Bilgi Teknolojisindeki Gelişmelerin Muhasebe Mesleğine Etkileri. N. Karg1 içinde, Bilgi Ekonomisi. Bursa: Ekin Yayınevi.

Venkatesh, V., Morris, M. G., Davis, G. B., \& Davis, F. D. (2003). User Acceptance of Information Technology: Toward A Unified View. MIS Quarterly, 27(3), 425-478.

Voutilamen, V., \& Pento, T. (2003). Electronic Invoice Processing As A Tool For Cost Reduction. Forntiers Of E-Business Research, 215-229. 
